CHINYERE N. ALIMBA, Center for Peace and Security Studies

Modibbo Adama University of Technology (Yola, Nigeria)

e-mail: chivoplc@yahoo.com,ORCID 0000-0001-5366-2559

\title{
WHY, WHERE, WHEN, AND HOW TO DOMESTICATING PEACE EDUCATION IN THE EDUCATIONAL SYSTEM IN NIGERIA?
}

\begin{abstract}
The nature and dynamics of social menaces within the educational system have frustrated and held its development hostage. The fundamental issues underlying this trend are value erosion and moral decadence, which have paved way for the distortion of the behavioural and attitudinal dispositions of the operators of the system. The blatant exhibition of discrimination, injustice, prejudice, envy, jealousy and conflict incidents within the educational system not only calls for, but necessitates the domestication of peace education as a panacea to these social menaces and a way to enhance the productivity of the system. Therefore, this study addressed the questions of why, where, when, and how peace education should be domesticated in the educational system in Nigeria. Thus, these questions underscore the focus of discussion in order to promote understanding and learning of the subject.
\end{abstract}

Key word: peace education; Nigeria's education system; peace education tasks; channels of peace education; goals of peace education.

\section{Introduction}

The importance of education in the growth of human society cannot be over emphasised. As the bedrock of human capital development, which culminated in the idea of an "economic man", education stands out as instrument per excellence for human transformation. Thus, the idea of economic man focuses on how the innate potentials of people are positively transformed through education to enhance their abilities and capabilities to make meaningful contributions to their personal improvement and the growth of their societies. This idea is substantiated by Fabunmi thus:

despite the rising cost of education, every nation strives to make education accessible to a greater percentage of its citizens, so as to increase its literacy level. Literacy level is acknowledged worldwide as a measure of development. The human capital theorists such as T.W. Schultz, M. Bowman, and G.S. Becker identified a link between investment in education and economic growth (Fabunmi, 1999:60).

These statements insightfully revealed that the provision of appropriate stock of skills will accentuate the potential and capabilities of individuals to make tangible contributions in accelerating the growth of their environments. The achievement of this laudable goal of human capital creation through education will depend on a number of factors, among which is how peaceful and conducive a society is. This is because an atmosphere of calmness and security play prominent and fundamental roles in the optimum productivity of a system. Nothing positive can possibly be created or achieved in an environment that is conflict ridden and violent oriented in nature. A clear illustration is the retrogression being experienced in Africa today, which has direct bearing with its vulnerability to incessant conflict incidences of varying magnitudes and intensities. Despite the democratic wave sweeping over the continent, its situation leaves much to be desired. This owes to extensive presence of armed conflict throughout the continent. The increasing conflicts in the continent in recent years can, to a large part, be explained by the incursion of the Islamic State (IS). IS has not only created new conflicts, but also fuelled existing ones (Conflict Trends, 2018). Moreover, the return of democracy in Africa in recent years after the spates of military interregnum has as well come with so much ruin because of the frequency and intensities of existing violent conflicts. In recent times, the common experience attests that 'the ballot' not the gun is slowly becoming the main source of political contestation, accompanied by a shift in focus to instability in urban rather than rural areas" (Cilliers, 2018). Thus, in Africa, violent protests have seemingly become acceptable public behaviour. By implication, the democratic system, which is expected to regulate conflicts for peace and stability as well as engendering meaningful social engagements, seems in a way, to be part of the problem, especially to the extent that new forms of criminalities and violence dominated the political space. Cilliers (2018) further indicated that new social tensions have emerged, such as increased criminality, parallel economies, youth violence, and gender-based and sexual violence. Also, it was reported that in "Africa, the number of non-state conflicts has increased dramatically in recent years, peaking in 2017 with 50 non-state conflicts, compared to 24 in 2011. By this statistics, Africa has the highest number of non-state conflicts" (Conflict Trends, 2018).

Thus, conflict in the larger society has a definite way of manifesting its antecedents in the subsectors that 
make up the entire polity. According to C.N. Alimba and O.F. Awodoyin (2009), developments in the society, impact considerably on the educational system and likewise the educational system on the society. The educational system manifests a fair share of the consequences of the crises because it is linked with developments in the society. Over time, the violent conflicts that occurred and are reoccurring in Africa have been manifesting adversely, in different ways, in the educational system. African Development Bank (2020) reported that in Africa, conflict afflicted countries have higher dropout rates, with children in these countries 30 percent less likely to complete primary school and 50 percent less likely to complete lower secondary school. In the same vein, conflict, which may be internal or external, equally have the potentials to affect teachers to the extent that it demotivates, demoralizes and retards progress in a school. In other words, conflict can dysfunctionally affect teachers' attitude to work, resulting in low morale and poor performance in schools (Jonkman, 2006). When teachers are dysfunctionally affected by conflict, it will reduce their productivity, thereby affecting the quality of education, and in the long run, the growth and development of a country (Alimba, 2017). Conflict, therefore, usually produces reverberating effects on the educational system in such a way that teaching, non-teaching staff and students will be adversely affected, which will subsequently manifest in the economy of a society. This is a clear indication that the goals of the system will be distorted to the point where its potential to create the desired human capital will be thwarted and the country will be robbed of people with the technical knowhow to cause the desired changes that will stimulate growth and development. School conflict often produces devastating effects on the system and generally on the society. C. Bogota (2009) described school conflict as any process that violates or affects the physical, social or psychological integrity of a person or group within the framework of school. School conflict can become violent especially when it is perceived wrongly and ineffectively handled. The most widespread forms of school conflicts are classroom disruption, discipline problems (conflict between teachers and pupils), abuse amongst pupils (bullying), vandalism, physical damage, physical violence (aggression, extortion) and sexual harassment (Bogota, 2009).

Thus, school conflicts are the incompatibilities that arise from specific issues in schools that have the capacity to thwart individuals as well as school goals (Alimba, 2016a). Therefore, no matter the angle school conflicts are viewed from, they are often inimical to the productivity of the system and the society at large. External conflicts which indirectly manifest in schools are rooted in bad governance, greed, structural problems such as discrimination, injustice, exclusion, poverty, unemployment, and sentiment. These 'external forces' are often extended into the school. They can, naturally, be explained within the gamut of human behaviour, mindset and attitudinal gap. This explains why peace education is considered necessary in addressing these problems. This is because they are based purely on the activities of human beings; hence, they are man-made in nature. Peace education has the potential to positively transform the behaviours and attitudes of people for their own good and the benefit of others. The idea of peace education arises from the fact that it can stimulate people to be peace-abiding, by developing in them values such as integrity, tolerance, justice, caring, respect for people, orderliness and honesty. Peace education is anchored on the philosophy of non-violence and helps to impart in people the skills, knowledge and attitudes that are germane to peacemaking values. The domestication of peace education in the educational system will create room for the promotion of trust, honesty, justice, equity, self-respect, compassion, cooperation, critical thinking and respect for people which are essential ingredients needed for behaviour modification and mindset transformation. According to C.N. Alimba (2008), peace education has the potential for behaviour modification and reorientation because of its potency to change the inner most parts of people through the acquisition of the rightful skills, knowledge and attitudes. This change is actually what is needed in addressing the criminality and violent conflict tendencies pervading the polity, which are directly affecting the educational system. The values that peace education propagates will aid in curbing corruption, embezzlement, hatred, crimes, marginalization, injustice, greediness, and bad governance which are the elements at the nerve of the crises rocking the system. In view of this, how peace education can be domesticated in the educational system to address these challenges is explored in this study. Therefore, the questions of why, where, when, and how can peace education be domesticated in the educational system formed the central thematic issues examined in this study. These themes are crucial to achieving the objectives of this study.

Understanding Peace Education and its Domesticating Paradigm. Peace education is a multifaceted and holistic education that takes into consideration the entirety of humanity and its environment. It is multifaceted because it encompasses different approaches that are capable of transforming the behavioural and attitudinal dispositions of people through the acquisition of the desired knowledge, skills and values needed for the creation and sustenance of peace. Its holistic tendencies sprang from the fact that it takes into consideration the whole body and soul, mind, heart and will (Quisumbing, 2000). Peace education therefore, is an elastic concept that can be employed to suit situations and needs in different cultural contexts. Seltz's (2004) illustrations aptly attested to the multifaceted nature and relevance of peace education in different cultural milieus. It was pointed out that in Japan, peace education was conceived as "anti-nuclear bomb education"; "education for mutual understanding in Ireland" and as "re-unification education" in Korea. Where as in countries in the southern hemisphere, peace education was considered as "development education" and in North America and Europe the discourse on peace education is guided by "conflict resolution education" (Seltz, 2004). These descriptions bring to mind two distinct characteristics of peace education: (i) peace education can be adopted in different socio-cultural contexts and (ii) peace education can be employed to solve diverse problems that manifest at micro and macro levels of social engagements. According to I.M. Harris and M.L.Morrison (2003), peace education is both a philosophy and a process that involves the acquisition of skills, attitudes and knowledge to create a safe world, to build a sustainable environment and to bring social change. As a philosophy, peace education is guided by a set of ideas, doctrines and principles which are centred on: (I) changing mindset; (II) cultivating a set of skills; (III) promoting human rights (particularly in Third World countries); and (IV) promoting environmentalism, disarmament and the promotion of a culture of peace (Salomon, 2002). As a process, peace education involves the development of programmes, procedures, activities, course of actions that can be imple- 
mented systematically to impart in people acceptable societal values needed to promote the development of authentic planetary consciousness that will enable people function as global citizens and to transform the present human condition by changing social structures and the patterns of thought that have created it (Reardon, 1988). Also, as a process, peace education promotes the knowledge, skills, attitudes and values needed to bring about behaviour changes that will enable children, youths and adults to prevent conflict and avoid violence, both overt and structural; to resolve conflict peacefully; and to create the conditions conducive to peace, whether at an intrapersonal, interpersonal, national and international level (Fountain, 1999).

Equally, peace education is a process which encompasses different approaches that are capable of transforming the behavioural pattern of people, through the inculcation of desired knowledge, attitudes, and skills for effective contribution to the cultural, social, economic and political development of their countries (Alimba, 2007).

Peace education is a problem-solving education that attempts to build in people values that are essential for transforming their behaviours and attitudes to ensure that they act in the right ways for the attainment of a culture of peace in a society. Peace education promotes skills and knowledge needed to change the behaviours and attitudes of people for the development of a non-violent mindset that will encourage peace and consequently sustain it in a society. Peace education is about empowering people with the skills, attitudes, and knowledge to: (I) build, maintain, and restore relationships at all levels of human interaction; (II) develop positive approaches towards dealing with conflicts from the personal to the international; (III) create safe environments, both physically and emotionally, that nurture each individual; (IV) create a safe world based on justice and human rights; and $(\mathrm{V})$ build a sustainable environment and protect it from exploitation and war (Harris, 2002). In essence, peace education is all about building peace at the micro and macro levels of social engagements in order to promote stability and security in a society. When implemented in a system or country, peace education can function as a framework for peace building (Alimba, 2010).

The essence of peace education is to create a culture of peace in a society, which is the central issue in the Hague Appeal. The Hague Appeal for Peace Global Campaign for Peace Education basically maintains that "a culture of peace will be achieved when citizens of the world understand global problems, have the skills to resolve conflicts and struggle for justice non-violently, live by international standards of human rights and equity, appreciate cultural diversity, and respect the Earth as well one another." These are indications that peace education is a multifaceted concept that can be implemented to address a whole lot of problems that are inimical to peace, the drive to achieve and sustain it. The idea is that a culture of peace can be achieved through the inculcation of skills and acquisition of knowledge germane to influencing the thinking patterns of people for constructive actions. Table 1 highlighted the basic skills, knowledge and attitude that can be acquired through peace education and that are favourable to the achievement of a culture of peace.

Table 1. Basic Skills, Knowledge and Attitudes of Peace Education

\begin{tabular}{|l|l|l|}
\hline \multicolumn{1}{|c|}{ Skill } & \multicolumn{1}{|c|}{ Knowledge } & \multicolumn{1}{c|}{ Attitude } \\
\hline - Critical thinking & Knowledge on issues relating to: & - Self-respect \\
- Problem solving & - Self-awareness & - Honesty \\
- Self-solving & - Peace and conflict & - Open-mindedness \\
- Self-awareness/reflection & - Justice and power & - Fair play \\
- Assertiveness & - Human rights & - Obedience \\
- Reading & - Globalization & - Caring \\
- Orderliness & - Duties and rights of citizens & - Empathy \\
- Perseverance & - Environment/ecology & - Tolerance \\
- Cooperation & - Social justice and power & - Adaptation to change \\
- Cheerfulness & - Non violence & - Sense of solidarity \\
- Self-control/self-reliance & - Conflict resolution and & - Respect for differences \\
- Sensitivity & - Culture and race & - Gender equity \\
- Compassion & - Gender and religion & - Sense of justice \\
- Active listening & - Health care and AlDS & - Sense of equality \\
- Patience & - Arms proliferation and drug trade & - Reconciliation \\
- Mediation & & - Bias awareness \\
- Negotiation & & - Tppreciation \\
- Conflict resolution & & \\
\hline
\end{tabular}

Source: (Alimba, 2010)

Table 1 revealed the skills, knowledge and attitudes that can be acquired by people through peace education. The acquisition of these values will empower people to develop the right frame of mind and the mindset to confront challenges in a non-violent manner to give peace a chance in a society. These values are a testimony to the fact that different problems can be tackled with different peace education val- ues, and when acquired by people, such values will shape people's thinking and ways of conduct in a society. D. BarTal (2002) posited that within the wide range of different peace education programme, a common general objective is to foster changes that will make the world a better, more humane place. Therefore, to achieve a safe world that will incubate and harbour peace and radiate its values, peace 
education should seek to diminish, or even to eradicate, a variety of human ills ranging from injustice, inequality, prejudice, and intolerance to abuse of human rights, environmental destruction, violent conflict, war and other evils in order to create a world of justice, equality, tolerance, human rights, environmental quality, peace and other positive features (Bar-Tal, 2002).

One way of ensuring that peace education programme effectively achieves its set goals is to domesticate it in a specific institution, system, community, country or region. Therefore, the idea of domesticating peace education is employed in this research work to describe a deliberate state whereby peace education programme is deeply and solidly embedded in a place, in such a way that people get accustomed to it as part and parcel of their lifestyles. In this sense, the necessary socio-cultural peculiarities of a place are duly considered to ensure its suitability and affability. In domesticating peace education, its values should be structurally programmed into the lifestyle of people in a compatible manner via their cultures. It is essential to ensure that when peace education programmes are propagated, they should be constructed to become part of the cultural formation of the place. In some contexts, the concept of 'institutionalisation' of peace education is favored more than domestication. However, since 'institutionalisation' is a contested term with diverse meanings (see Crossan, Lane and White, 1999; Crossan and Bedrow, 2003; Schneiberg and Soule, 2005), the current study favours domestication. This is because peace education involves the selection of values deemed necessary for a particular environment for propagation to overcome prevailing challenges in order to achieve peace. However, the study's favourable disposition to the use of 'domestication of peace education' does not entirely dispel "institutionalisation of peace education" or regard it as completely irrelevant.

Why Domesticating Peace Education in Educational System. The factors that call for the domestication of peace education in the educational system in Nigeria are diverse, and they are based on social, economic, political, and environmental issues. These factors are responsible for the experiences of dysfunctional outcomes such as conflicts, discrimination, injustice, corruption, insecurity, bad leadership and the likes in the system. These problems can equally be induced externally. However, whether they are provoked by internal or external influence, they often produce unimaginable adverse effects on the educational system. The external problems are those caused by the government or its agencies, which extends to the system, while the internal problems are those generated within the system. This is an indication that the educational system is entangled in the web of indescribable proportion of social, economic and political maladies in Nigeria. Since Nigeria's return to democracy in 1999, public expectations have been derelict due to the manifestations of different forms of violent conflict, criminalities and abuses in the polity. This worrisome situation has undermined investment and tourism; contributed to small arms proliferation; aggravated human rights abuses and mass displacement, destruction of both public and private infrastructures; increased violent conflicts; distorted national cohesion; and caused resource diversion.

Considering the fact that the educational system is the subset of the larger society, what goes on in the system is a function of what is happening at the macro level of the society. Schonfeld and Newgass (2003) attested to this scenario that the episodes of violence at our schools remind us that schools are an integral part of their communities and therefore are vulnerable to the influences and factors that are present in the larger communities. The antecedents of societal incidences usually affect education in two ways. First, it normally brings about decline in resource allocation, and this often produces overbearing impact generally on the system, due to the level of resources devoted it for the execution its activities. This has pushed the educational system to the precipice of operating under a tight budget at all level, preventing its effective and efficient operations. The second way relates to its impacts on human resources. Teaching, non-teaching staff and students have been a serious issue in the system. For instance, the inability of the system to support its students in terms of provision of basic facilities needed for teaching and learning often lead to the formation and exhibition of different forms of behavioural and attitudinal decadence among them in the forms of joining secret cults, increased acts of gender violence, constant manifestation of student unrest, rising cases of examination malpractices and so on. The resultant effects of these vices are the manifestation of students' poor performance, low quality of outputs, poor standards and, ultimately, low quality of education. M. Fabunmi (2020) asserted that the dwindling economic fortunes of the country have culminated into persistent economic instability, which has led to under-funding of education and also denied the school-age population equal access to good quality education. This view shows a functional link between development in the nation and consequently on its educational system. Thus, what is happening in a society has the potential to greatly shape what goes on in education, especially in terms of producing quality workforce and good quality education. On the other hand, the internal conflict dynamics in the educational system clearly provoked the need to embrace peace education. The dimensions and intensities of conflicts existing in schools are rather frustrating and devastating in nature. According to C.N. Alimba (2016a), the school is a conflict-ridden environment and has been classified as the highest conflict brewing organisation. Conflict of different magnitudes and intensities exist in the system from interpersonal to intergroup levels. Some of the interpersonal conflicts often recorded in school may be categorised as student to student conflict (SSC), teaching staff to student conflict (TSSC), teaching staff to teaching staff conflict (TSTSC), conflict between teaching staff and non-teaching staff (TSNTS), non-teaching staff to student conflict (NSSC), non-teaching staff to management conflict (NSMC) and teaching staff to management conflict (TSMC).

Equally, some of the intergroup conflicts present in the system especially at the higher levels are conflict between academic staff unions and non-academic staff unions; academic staff unions and management conflict; non-academic staff union and management conflict, student union and management conflict and also conflicts occasioned by these unions and government. The perception is that these unions and their leaders are perceived as the incorrigible trouble makers, hell-bent on causing mischief and in giving perpetual headache to the administrators of their respective institutions as well as the government, the funder of these institutions (Jega, 1996). The unions are actually set up to fight for the welfare of their members and the state of their institutions. However, depending on the leadership, their agitations may be misconstrued as unwarranted and selfish in nature. Apart from the conflict manifesting in the system, there are also attitudinal problems such as dissension, anger, mistrust, envy, jealousy, greed, discrimination and 
injustice which have dispose the system to a high state of uncertainty and insecurity. These challenges have rendered the educational system highly unproductive in achieving its set goals. Also, the connection between education and the society has continued to fuel grievous antecedents on the human population in an alarming manner. The dynamics of the decadence have robbed the educational system the supposed peace and security that are needed for effective and efficient conduct of activities in the system. For instance, a study reported "that teachers are affected by different scales of conflict meted against them from the external sources and by students. They also suffer symbolic violence through discrimination in relation to their cultural, race, ethnic, linguistic or socioeconomic backgrounds" (Novelli and Sayed, 2016). The study further implicated teachers also as perpetrators of violence not only against students, but also on fellow teachers. Furthermore, teachers may enact symbolic violence through discrimination in relation to the cultural, race, ethnic, linguistic or socio-economic backgrounds of students (Novelli and Sayed, 2016). The schools in Nigeria equally reflect situations of this nature, because there are cases of teachers fighting with other teachers as well as students attacking teachers, and teachers equally dealing with students in a manner unacceptable.

The level of moral decadence in the educational system is alarming and extremely frustrating. M. Fabunmi (2019) pointed out that fraudulent obsession for material gains and positions, ethnicity and nepotism now seem to be the order of the day in the Nigerian educational system. The author observed further that some scholars are commercialised, while a few are academic. Students no longer read, they are said to be 'blocking' their failures with monetary and sexual gratification. The end result of this immoral act is that "most of the products of the educational system seem to be certificated illiterates (Fabunmi, 2019: 6). The issue of transparency is no longer given the deserved attention. In fact, there are several unreported cases of breach of due process and justice perverted in schools. These issues raise the question of where lies integrity in the system (Fabunmi, 2019: 7). These challenges are purely antecedents that are based on the conducts of people, occasioned by behavioural and attitudinal deficiencies. However, D. Bar-Tal (2002), established that peace education "changed attitudes, increased tolerance, reduce prejudices, weakened stereotypes, changed conceptions of self and of "other" and reinforced sense of collective identity in people. Bar-Tal's postulation is greeted with some validity because the various behavioural and attitudinal decadences stimulating these vices can be addressed through values acquired by peace education. By implication, peace education has the potency to change the system and consequently the society for good, by positively transforming the individuals operating the system as well as the students. Thus, the transformative power of peace education should propel its domestication in the educational system.

The Question of Where to Domesticate Peace Education. Peace education can be embraced anywhere and anytime; it all depends on what to be achieved. The elastic nature of peace education permits its implementation at any place. However, it is particularly most suitable and expedient in the educational system because of: (I) wider coverage of large audience and the linkages of the educational system with other subsectors in the country; (II) the highly coordinated nature of the educational system will allow for the effective and efficient operations of peace education programme for a better outcome; (III) the possible ease of monitoring and evaluating peace education to pave ways for adjustment and improvement were necessary to achieve set goals; and (IV) the promising ease of sourcing and training implementers of peace education in the educational system; that is, the needed human resources required for carrying out peace education activities will be drawn from the system. The choice of the educational system as a place where peace education should be domesticated is imperative to create a deeper effect in terms of outcome. Figure 1 highlights the link between the educational system and other sectors of the economy.

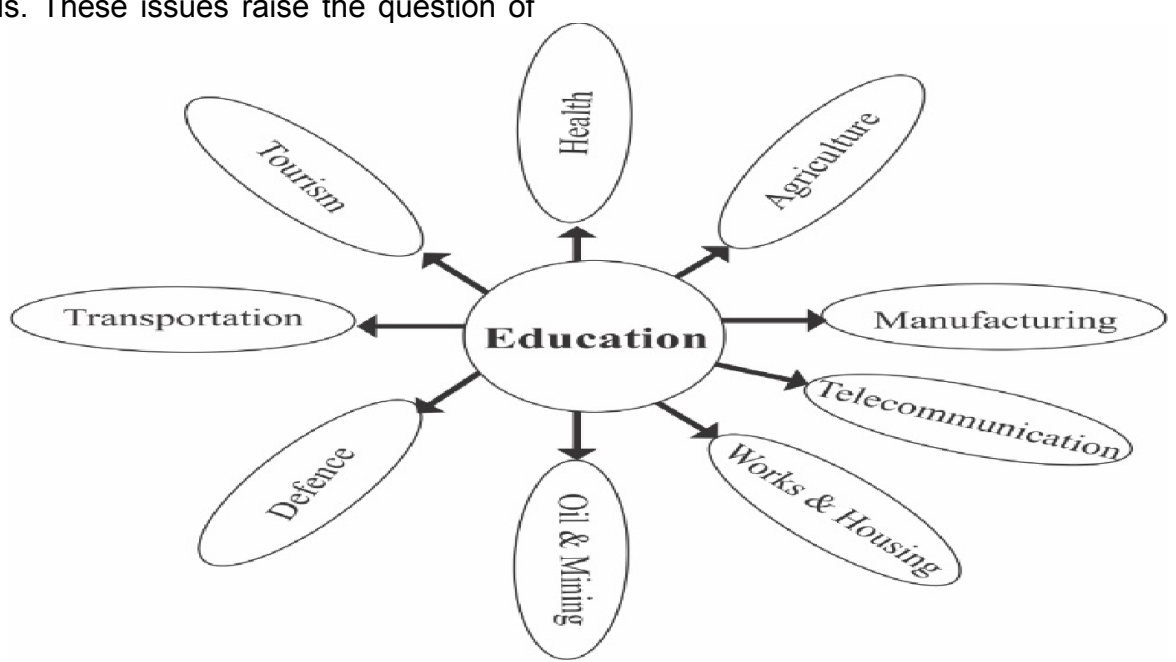

Fig. 1. Link between Education and other Major Sectors

It is clear from figure 1 that domesticating peace education in the educational system will cause a dynamic flow of those trained to other sectors. This, therefore, implies that people from different backgrounds will have access to the programme, increasing the scope of its recipients and the reach. This will make the impacts of peace education to be pronounced in the country. The uniqueness of the educa- tional system based on how it is organised, controlled and activities conducted and delivered gives the impression that its usage will serve as a means to an end. Therefore, seeing the educational system as a veritable point to host peace education, the idea of where to domesticate it is still an issue because it is made up of different levels. Figure 2 shows the different levels of the educational system. 
Levels of Education

\begin{tabular}{|c|c|}
\hline Pre-Primary Education & * Socio-cultural peculiarities \\
\hline & $\begin{array}{l}\text { of a particular level } \\
\text { * Pedagogical issues }\end{array}$ \\
\hline Primary Education & * Teaching Methodology \\
\hline & $\begin{array}{l}\text { and approaches } \\
* \text { Curriculum Design }\end{array}$ \\
\hline Secondary Education & * Leaner's Background \\
\hline & $\begin{array}{l}\text { and Characteristics } \\
* \text { Nature of Peace Education }\end{array}$ \\
\hline Tertiary Education & Values to propagate \\
\hline
\end{tabular}

Factors to consider for

where to domesticate Peace Education

Fig. 2. Levels of Education and Factors influencing Peace Education
Figure 2 showed the different levels of education and the factors that should be considered for the domestication of peace education. These factors are relevant to the levels of education where peace education will be housed. It is necessary to understand the importance of the distinctiveness of the levels of education, for the issue of where to be adequately addressed. The question of where can best be answered when the goal of peace education is ascertained in relations to the problem to be addressed. Then, the level of education to target becomes crucial for the implementation of the programme. This is fundamental because how peace education will be organised and implemented in the preprimary education will be different from how it will be conducted in primary education as well as secondary and tertiary levels. Therefore, where to domesticate peace education is so crucial because it has bearing on how peace education activities will be carried out to achieve its purpose.

When to Domesticate Peace Education. If there is any time that peace education is most needed, it is now. The 21 st century is readily ripe for peace education programme, because of the manner in which violent conflicts are occurring and the rampant exhibition of unwanted behaviour in societies occasioned by the phenomenon of globalisation. This is the reason why at the dawn of the 21st century, the International Decade for a Culture of Peace was launched from 2001 to 2010 by the United Nations, commemorating the imperativeness and relevance of peace education at the moment. In recognising the United Nations' call due to the ripeness of peace education, nations around the world are massively subscribing to it. This shows that peace is highly needed and should be given a chance to reign at this critical stage of human development. As at 2002, the Stockholm International Peace Research reported that:

The world possesses 7150 nuclear warheads and nearly 36,800 potential nuclear warheads that have posed a very serious threat to the survival of mankind. Even though this warstricken gloomy picture of the world is only one side of the coin and there is much to be optimistic about, particularly the evergrowing realization by peoples regarding the indispensability of peace in a world which has well and truly become a global village under the impact of numerous dynamics.

This report implies that attaining peace has become a critical issue in the history of mankind, and to achieve it, a special kind of education should be provided for individuals in this era of global village. This special education should be such that will incorporate and reflect the tenets and antecedents of peace, and should be critically structured to reflect and impart peace. Peace education is that special kind of education that can educate people for peace. Around the world, peace education has become a sine quo non for the development of non-violent behaviour needed for peace building in order to create a pathway for the emergence of a culture of peace. According to T. Komatsu (2017), in this time of globalisation which challenges the nation-state paradigm, research on education and peace is more important than ever, and can significantly contribute to the discussion of human security, or protecting human lives and livelihoods. This moment can best be described as the age of peace education, because it is a major subject that has attracted the attention of countries worldwide to ensure the achievement of a culture of peace. In the context of Nigeria, where the incessant recurrence of conflicts has jeopardised the fruitfulness of the democratic system, embracing peace education is a crucial step in the right direction. The manner in which conflicts is present in the polity is well captured by C.N. Alimba and N. Salihu (2020). They reported that:

the crises have assumed regionally based dimensions: the six geopolitical zones are plagued with different forms of violent conflict. The resource crisis and kidnapping remain largely unabated in the south-south zone, while high cases of criminality are prevalent in the southwest zone of the country. The southeast is home to various nationalist agitations, criminality, and kidnapping. Ethnic conflict tinted with religious colouration, farmerherder conflict, and communal violence continued to manifest in the north central zone, while cattle rustling coupled with armed banditry, farmer-herder conflicts, kidnapping are on the increase in the northeast and northwest zones of the country (Alimba and Salihu, 2020: 44)

These developments have resulted in a state of insecurity, as many people were killed and displaced, properties and livelihood ventures destroyed with impunity, thereby implicating trust in communities, where people have lived peacefully with one other for decades. It is clear that these events signal the fact that peace education should be made mandatory in schools to help in developing peacemaking virtues that will promote peace and security in the country. This is the reason why researchers have considered the preparation of a curriculum for peace education in Nigeria as a worthwhile 
academic enterprise at this time of our national development (Fabarebo, Sangotunde and Ojetayo, 2019). Peace education has become a subject of discussion in official and academic circles, with particular focus on how to domesticate it in order to provoke peaceful atmosphere that will enhance growth and development in the country. Scholars have been making frantic efforts in dishing out researches on the subject for its better exposition and exploration to increase understanding and learning about the importance of peace and security in the country.

How to Domesticate Peace Education. In a world filled with the images of armed violence, death, harm and pain, peace education becomes imperative so as to ensure that individuals develop peacemaking mindset so that they can live in harmony with others. This is the most effective time to engage in peace education activities so that people, especially younger minds, can learn about the elements of peace and how they can constructively mitigate conflict. This is based on the fact that peace education has the potential to transform cultures of violence to culture of peace and it is a lifelong learning that is, from childhood socialisation to adult education (Rank, 2012). For the needed atmosphere to be created for the domestication of peace education, will depend on the understanding of its types and channels for its propagation. These are important issues that underpin how peace education will be domesticated. According to I. Harris (2004), the various types of peace education are: (I) conflict resolution education; (II) human rights education; (III) environmental education; (IV) international education; and (V) developmental education. Equally, another type of peace education missing in the list, but which has been acknowledged is spiritual education (Alimba, 2016b). Spiritual education is very essential, but it is less considered by scholars. It is one of the most important aspects of peace education (Alimba, 2016b). Having identified the various types of peace education, another issue circumscribing the domestication of peace education is the outlets for its propagation. The outlets are the channels through which peace education is dispensed. It was advanced that for peace education to achieve its set target, the channels of propagation, implementation pattern and resources to be used should be given a priority attention (Alimba, 2013). The channels are the informal, formal and non-formal channels.

The informal channel of propagating peace education involves development at home and family settings, which have bearing on how peaceful behaviours are nested and promoted. This channel is characterised by approaches that border on role model, imitation and other means such as storytelling, proverbs, use of poems etc in homes, families and the immediate environment. The formal channel entails the use of schools to educate people for peace. It involves the incorporation of peace education values into the school curriculum, so that people can be taught how to pursue peace with self and others in the environment. Non-formal channel of peace education involves training people through workshops, seminars and conferences at the local level, so that they can be aware of how to live peacefully and harmoniously with others (Alimba, 2013:341).

This illustration revealed that these channels are indispensable for dispersing peace education in order to achieve its set goals. The corrective and therapeutic functions of peace education can be put into action when the channels are adopted in relation to the problem to be addressed. In this paper, the formal channel, which has to do with the formalisation of peace education in the educational system, is considered for adoption. This has the advantage of being extended to a wider audience. I.O. Albert (2014) posited that "formal peace education is provided by academic institutions whether primary, secondary, and tertiary. It is based on careful crafted and well-tested epistemological, pedagogical, theoretical and methodological frameworks". Thus, peace education in schools of education occurs through infusing peace and justice concepts into existing curricula (Harris, 1999). Despite the use of infusion method in operating peace education in schools, C.N. Alimba (2018) opined that peace education curriculum should take into consideration local peculiarities and orientations in its development. This is because it is likely that any programme of peace education would be different from many other aspects of formal education (Harber and Sakade, 2009). The different forms of peace education should be guided by local peculiarities in the forms of "the problem to be solved, the structural orientation of a place, in terms of its diversity, the orientations of the people and resources required for conducting the programme"(Alimba, 2018).

Therefore, understanding the above issues will bring to focus the need to discuss the approaches that can be adopted in domesticating peace education in the school setting, which are: (I) taking peace education as a subject; (II) designing peace education to take the form of a course; and (III) presenting peace education as a programme. Domesticating peace education as a subject involves teaching it as a topic, contained in all the subjects being taken by students at different levels of education. In doing this, it will serve as a prism through which students will learn to view and evaluate topics and issues raised in the various subjects, and through this process, they will learn to view and evaluate the peace process (Bar-Tal, Rosen and Nets-Zehngu, 2009). Teaching peace education as one of the contents of different subjects should be systematic in such a way that the conflict incidences that took place or that are occurring should be used as case studies to discuss their causes and costs, to the extent that attempts made at resolving them and the end results should be made known to students with their limitations and implications. Each conflict scenario has its own uniqueness and peculiarities which should be logically presented to students to influence their understanding that there is nothing good about indulging in conflict as a means of resolving differences. In line with these ideas, D. Bar-Tal, Y. Rosen and R. Nets-Zehngu (2009) observed that

in teaching this subject, referring directly to the particular conflict, should begin with the description of the violent conflict in which the society was involved and the heavy price it paid and move on to the peace process that started, with its difficulties and achievements, and refer to the differential but dynamic relations between one's own society and different segments of the rival society (p.33).

It is clear from this presentation that conflict scenarios vary in terms of causes, costs and parties involved, and these elements should be logically presented to students to help them understand the need to resolve conflict constructively, so that peace and harmony can be guaranteed in societies. The major limitation of this approach is that the scope, in terms of the areas that will be covered, may be limited given the fact that students have so many subjects to be taught, of which peace education is a fractional part. Another limitation is that since peace education is just an insignificant part of what will be taught in a subject, the likelihood is that the teacher may not be a trained peace educator. This is a serious problem be- 
cause lessons may likely not be presented the way a peace scholar would do it. In designing peace education to take the form of a course, it will be taught as a unit of individual subject usually by an instructor or instructors in which students are graded at the end of an academic term. For instance, in most tertiary institutions in Nigeria, peace and conflict resolution is being taught as a course in General Studies (GS) programme for undergraduate students.

By teaching peace education as a course, the scope of what to cover will marginally be wider and more lessons will be learnt. A. Simmons (1984) maintained that the inclusion in curriculums, courses and readings relating to peace and international security is not only timely, but critical. This is due to the incessant manner in which injustice and violence occur in interpersonal and intergroup relations. Presenting peace education as a programme in the school setting, implies that will lead to individuals to obtain a degree certificate to become a certified peace practitioner. A programme is a combination of courses that lead to graduating with a degree in a higher education, in which individuals will gain an in-depth knowledge and acquire skills that will make them to be peace educators or actors in a society. The universities in Nigeria are beginning to subscribe to peace and conflict resolution as a degree programme. This development started at the University of Ibadan in 2001, when Peace and Conflict Studies programme was mounted at the Institute of African Studies to award Degree in Masters to students that undergo the programme. Since then, so many universities, including Modibbo Adama University of Technology, Yola, offer it as a course at the undergraduate and as a programme at postgraduate level. This will help to increase the number of peace practitioners, paving way for increased availability peace educators and practitioners in the country. The production of more peace practitioners is essential because researches found a lack of systematic evaluation of the effectiveness of peace education programmes (Fountain, 1999; Nevo and Brem, 2002). The reason for this attitude may be rooted in 'the low level of awareness regarding the importance and usefulness of the programme; a lack of expertise in evaluation methodology; budgetary considerations; and avoidance tactics'(Nevo and Brem, 2002). Thus, the raising of more peace educators will increase awareness about the programme, overcome the challenge of expertise and prevent the avoidance tactics against the subject. To domesticate peace education at any of the level of education, there is need to comprehend the peace education implementation tasks presented below. Figure 3 is the peace education implementation tasks.

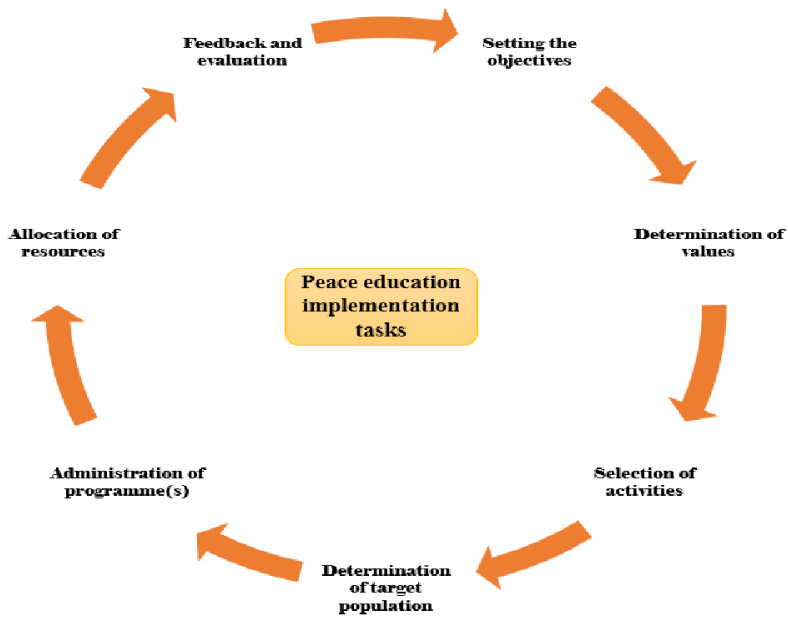

Fig. 3. Peace education implementation tasks (adapted from (Alimba, 2007))

Fig. 3 showed the peace education implementation tasks. The tasks consist of seven activities which should be followed currently in order to achieve set goals. The tasks involve setting the objectives, determination of values, selection of activities, determination of target population, administration of programme, allocation of resources, and feedback and evaluation. In setting the objectives, the problems to be addressed with peace education should be clearly and succinctly identified. Then, the peace education values that can confront the problems will be determined. Thus, determination of values that are capable to address the identified problems is conducted. Such values could be tolerance, justice, transparency, respect for others, and the likes. However, the selection of the values should be conducted in relations to the problems to be solved. Selection of activities involves determining the level of education in which the peace education values will be hosted and administered. After doing this, the issues of whether to operate it as topics in subjects, as a course or programme will be determined. This will help to influence how the curriculum will be designed for impartation. The determination of target population involves identifying the group that the programme should aim at in the school setting. When this is ascertained, the curriculum will be adapted to suite such group. In the administration of programme, the issues of how and when to administer the programme are equally germane to its success. Resources required for the implementation of the programme should be made ready. The allocation of resources, whether material, human and financial, should be diligently sourced in the required quality and quantity. The feedback and evaluation of the programme should be meticulously conducted to determine and ensure the correction deviations for the success of the exercise.

\section{Conclusions}

In this article, the issue of domesticating peace education in the educational system was painstakingly and criti- 
cally interrogated to promote understanding and learning. This is essential in raising awareness and consciousness on the efficacy of peace education as a means of combating the menace of armed violence in human societies. The volume of armed violence being experienced worldwide has increased the level of fatalities, the debacle of displacement and refugee, destruction of properties and livelihood ventures of people and increased the risk of insecurity. Also, the issue of moral decadence is part of the issue robbing societies of their expected peace and security. Therefore, employing peace education as a model for learning to abolish war and moral problems has become imperative to foster individuals to acquire the needed knowledge, skills and attitude for the development of non-violent behaviour required for peace making and peaceful living in societies. Peace education is important for all. However, exposing children who are still in the process of forming their values to peace education will be more effective. This is because when children are taught to be peaceful, they will grow up abiding by the values they have acquired, standing as role model for others and the upcoming generations. When this happens, the impact will create a ripple effect which will cause the creation of a culture of peace in the society. Thus the analysis of what, where, when and how to domesticate peace education has been interrogated with the aim of promoting awareness about it. Equally, the peace education implementation model developed by the author was employed to illustrate how to go about executing tasks for the expected outcomes to be achieved effectively. Therefore, when peace education is properly domesticated, the skills, knowledge and attitudes that will be acquired will help to tackle diverse problems confronting the educational system and the society in general.

\section{REFERENCES}

African Development Bank (2020) African Economic Outlook 2020: Developing Africa's Workforce for the Future. African Development Bank Group, Abidjan, Côte d'Ivoire.

Albert, I.O.(2014). Peace Studies and Practice in West Africa. Ibadan Journal of Peace \& Development, 3\&4 (May): 1-15.

Alimba, C.N. (2007). Tackling Examination Malpractices in Nigeria through Peace Education. Journal of Sociology and Education in Africa, 6(1): 27-44.

Alimba, C.N. (2008). The Place of Peace Education in achieving the Millennium Development Goals in Nigeria. International Journal of Educational Research and Administration, 5(1): $76-81$.

Alimba C.N. and Awodoyin, O. F.(2009). Disarmament education: An imperative for effective management of education for sustainable development in Africa. International NGO Journal, 4 (12): 491-497. Retrieved from https://academicjournals.org/journal//NGOJ/article-full-text-pdf/AB6F6BE40373

Alimba, C.N. (2010). Peace Education: An Untapped Pathway to Managing Ethno-Religious Conflicts in Nigeria. In Albert I.O. and Olarinde, O.N. (eds) Trends and Tensions in Managing Conflicts. Abuja: Society for Peace Studies and Practice.

Alimba, C.N. (2013). Peace Education, Transformation of Higher Education and Youths Empowerment for Peace in Africa. International Journal of Scientific \& Technology Research, 2(12): 338-347. Retrieved from http://www.ijstr.org/paperreferences.php?ref=IJSTR-1213-7807

Alimba, C.N. and Isah, E.A.(2016). Tackling the Socio-Cultural and Political constraints confronting Vocational/Technical Education through Peace Education in Nigeria. British International Journal of Education and Social Sciences, 3(3): 52 64. Retrieved from http://cird.online/BIJESS/index.php/march-2016/

Alimba, C.N.(2016a). School Conflict: What Teachers should Know. International Journal of Capacity Building in Education and Management, 3(1):33-45. Retrieved from https://rcmss.com/2016/ijcbem/july/School\%20Conflict\%20What\%20Teachers $\% 20$ Should\%20Know.pdf

Alimba, C.N. (2016b). Peace Education: A Panacea for Quality Assurance in Higher Education in Africa. International Journal of Peace and Conflict Studies, 3(1): 19-31. Retrieved from http://www.academix.ng/search/paper.html?idd=3300017084

Alimba, C.N. (2017). Dysfunctional Consequences of Conflict on Teachers' Productivity: A Theoretical Insight. International Journal of Arts and Humanities, 6(1): 146-161. DOI: https://doi.org/10.4314/ijah.v6i1.13

Alimba, C.N. (2018). Peace Education Curriculum: Issues and Perspectives in Nigeria. International Journal of Educational Planning and Administration, 3(4\&5): 391-406.

Alimba, C.N and Salihu, N. (2020). Understanding the Root Causes of Boko Haram Insurgency in Nigeria: A Perception Study. Ethnic Studies Review, 43(2): 43-57. DOI: https://doi.org/10.1525/esr.2020.43.2.43

Bar-Tal, D. (2002). The Elusive Nature of Peace Education. In: Salomon, G. \& Nevo, B.(eds), Peace Education: The Concept, Principles, and Practice around the World. Mahwah, NJ: Lawrence Erlbaum.

Bar-Tal, D., Rosen, Y., and Nets-Zehngu, R. (2009). Peace Education in Societies Involved in Intractable Conflicts. In: Handbook on Peace Education, Routledge. DOI: https://doi.org/10.4324/9780203837993.ch3

Bogota, C. (2009). The Hermes Programme for Conflict Management at School. Bogota Chamber of Commerce, Colombia.

Cilliers, J. (2018). Violence in Africa Trends, drivers and prospects to 2023. Institute of Security Studies. Pretoria, South Africa.

Conflict Trends (2018). Conflict Trends in Africa, 1989-2017. Peace Research Institute Oslo (PRIO), Norway.

Crossan, M. \& Bedrow, I. (2003). Organizational learning and strategic renewal. Strategic Management Journal, 24 (11): 1087-1105. DOI: https://doi.org/10.1002/smj.342

Crossan, M., Lane, H. W., \& White, R. E. (1999). An organizational learning framework: from intuition to institution. Academic Management Review, 24, 522-537. DOI: https://doi.org/10.2307/259140.

Fabarebo, I.S., Sangotunde, S.O. and Ojetayo, K.G. (2019). The Peace-Education Curriculum Desirable for PrePrimary and Primary Schools in Nigeria: A Religious Perspective. European Scientific Journal. January, 15(1): 214-228. DOI: https://doi.org/10.19044/esj.2019.v15n1p214

Fabunmi, M.(1999). Strategic Planning of Education in Nigeria. African Journal of Educational Management, 7(2): 60-65.

Fabunmi, M. (2019). Management in Education: The Integrity Question. 24th Inaugural Lecture, Delivered on the 10th April, 2019 at Modibbo Adama University of Technology, Yola

Fabunmi, M. (2020). Public-private Partnership Models for the Promotion of Economic Stability and Access to Quality Education in Nigeria. Lead Paper presentation at the first National Conference of Faculty of Education, Bayero University on the 12th-15, January 2020.

Fountain, S. (1999). Peace Education in UNICEF. Working Paper Education. Section Programme Division, New York: UNICEF.

Harber, C. and Sakade, N. (2009). Schooling for violence and peace: how does peace education differ from 'normal' schooling? Journal of Peace Education, 6(2): 171-187. DOI: https://doi.org/10.1080/17400200903086599.

Harris, I. M. (1999). Types of peace education. In A. Raviv, L. Oppenheimer, \& D. Bar-Tal (Eds.), How children understand war and peace: A call for international peace education. (pp. 299-317). San Francisco: Jossey-Bass.

Harris, I. (2002). Conceptional Underpinnings of Peace Education. In: Salomon, G. and Nevo, B. (eds) Peace Education: The Concept, Principles and Practices Around the World. N.J: Lawrence. Erlbaum.

Harris, I.M. and Morrison, M.L. (2003). Peace Education. London: McFarland and Co. 
Harris, I. (2004). Peace Education Theory. Journal of Peace Education. 1(1): 5-20. DOI: https://doi.org/10.1080/1740020032000178276

Jega, A.M. (1996). Unions and Conflict Management in Nigeria's Tertiary Institutions. A Journal of Opinion, 24(1): 61-63. DOI: https://doi.org/10.1017/s1548450500004984

Jonkman, D. (2006). Management of Conflict by Principals in Selected Soshanguve Secondary Schools. M.Ed Dissertation. Dept of Educational Studies, Faculty of Education, Tshwane University of Technology, South Africa. ix+86pp.

Komatsu, T. (2017). Education And Peace. The Oxford Research Encyclopedia, Education. Oxford University Press, USA.

Nevo, B. and Brem, I. (2002). Peace Education Programs and the Evaluation of their Effectiveness. In: Salomon, G. and Nevo, B. (eds.) Peace Education: The Concept, Principles and Practices around the World. Mahwah (NJ): Lawrence Erlbaum Ass.

Novelli, M. and Sayed, Y. (2016). Teachers as Agents of Sustainable Peace, Social Cohesion and Development: Theory, Practice \& Evidence. Education as Change, 20( 3): 15-37. DOI: https://doi.org/10.17159/1947-9417/2016/1486

Quisumbling, L.R. (2000). Educating Young Children for Peaceful World.Second World Forum on Early Care and Education. 16-19 May, Singapore.
Rank, C. (2012). Peace Education. Module MO2ISS, 13 December, Coventry: Coventry University.

Reardon, B. (1988). Comprehensive Peace Education. Education for Global Responsibility. Teacher College Press, New York.

Salomon G. (2002). The Nature of Peace Education: Not All Programs Are Created Equal. In: Salomon, G. and Nevo, B. (eds) Peace Education: The Concept, Principles, and Practices Around the World. Lawrence Erlbaum Associates, Publishers Mahwah, New Jersey, London.

Schneiberg, M. and Soule, S.A. (2005). Institutionalisation as a Contested, Multilevel Process. In: Social Movement and Organisation Theory, Davis, G.F.; McAdam, D; Scott, W.S and Zald, M.N.(eds). Cambridge University Press.

Schonfeld, D.J and Newgass, S. (2003). School Crisis Response Initiative. OVC Bulletin, September. DOI: https://doi.org/10.1037/e532222006-001.

Seltz, K.(2004). Education and Conflict. The Role of Education in the Creation, Prevention and resolution of Social Crises: Consequences for Development and Cooperation. German: DeutcheGessellschaftfurTechnischeZusammenarbelt (GTZ) Gmbtt.

Simmons, A. (1984). War, Peace and Liberal Flucation. Bulletin of Atomic Scientists, 40(10): 35.

Жиньср Н. Алімба,

Центр досліджень миру та безпеки,

Університет Технології Модіббо Адама (Йола, Нігерія)

e-mail:chivoplc@yahoo.com,ORCID0000-0001-5366-2559

\section{ЧОМУ, ДЕ, КОЛИ І ЯК ЗАПРОВАДИТИ МИРОТВОРЧУ ОСВІТУ В ОСВІТНЮ СИСТЕМУ НIГEPIÏ?}

Характер та динаміка соціальних загроз в освітній системі Нігерії утруднюють та стримують їі розвиток. Основними проблемами, що лежать в основі цих загроз, є ерозія суспільних цінностей та моральний занепад, які відкрили шлях до спотворення поведінкових та настановчих диспозицій операторів системи. Кричуща демонстрація дискримінації, несправедливості, упереджень, заздрості, ревнощів та консрліктних ситуацій в освітній системі вимагає упровадження в національну освітню систему концепції миротворчої освіти як панацеї від цих соціальних загроз та способу підвищення продуктивності системи. У дослідженні розглянуто питання, чому, де, коли і яким чином концепція миротворчої освіти має бути інтегрована в освітню систему Нігерії. Автор доводить, що результатом їі впровадження має стати набуття учнями навичок, поглядів і знань для створення безпечного середовища проживання, сталого довкілля та соціальних змін. Змістом роботи з упровадження такої концепції він вважає розробку програм, процедур, заходів, дорожніх карт, які можуть бути реалізовані систематично, щоб прищепити людям прийнятні суспільні цінності, необхідні для сприяння розвитку справжньої планетарної свідомості, яка дозволить людям функціонувати як глобальні громадяни і змінити нинішній стан людини, змінивши соціальні структури і моделі мислення, які його зумовили.

Ключові слова: миротворча освіта; освітня система Нігерії; завдання миротворчої освіти; фрактори впливу на миротворчу освіту; фуннції миротворчої освіти

(c) Chinyere N. Alimba

Надійшла до редакції: 29.07.2020

Прийнята до друку: 07.09.2020 